\title{
Impact of Green Innovation, Cultural Environment, Company Performance During Covid-19
}

\author{
Supriyanto ${ }^{1, *}$ Suripto ${ }^{1,}$ Mohammad Benny Alexandri ${ }^{2,}$ Putri Irmala Sari ${ }^{1}$ \\ ${ }^{1}$ Department of Business Administration, Faculty of Social and Political Science, Lampung University, Indonesia, \\ ${ }^{2}$ Department of Business Administration, Padjadjaran University, Indonesia, \\ *Corresponding author. Email: supriyanto.1989@fisip.unila.ac.id,
}

\begin{abstract}
The purpose of this study is to determine the awareness of oil and gas companies who are involved in inexperienced innovation practices and have an impact on corporation performance. Especially from the effect on the cultural environment on corporation performance, with inexperienced innovation as a mediating variable for oil and gas corporations listed on the Indonesia Stock Exchange in 2019-2021 for the period of the Covid-19 pandemic. The populace in this study are oil and fuel corporations listed on the IDX. The method used in this research is quantitative. The statistics gathered have been 10 oil and gas companies 2019-2021. The results of this study indicate that the cultural surroundings have a fantastic effect and are confirmed to have a sizable impact on agency overall performance which is mediated by green innovation. The originality of this research includes: the use of green innovation via oil and fuel groups all through the Covid-19 pandemic as a mediator - something that has never been done with the aid of different researchers, specifically in Indonesia; dimension the usage of most important records on an ordinal scale, and inspecting oil and gas corporations.
\end{abstract}

Keywords: Green Innovation, Environment Culture, The Performance of Oil and Gas Companies, Covid-19.

\section{INTRODUCTION}

The era of globalization in the era of 4.0 precipitated climate change and international warming to be discussed via all countries in the world which led to opposition between state groups in becoming a steady environment. Where the competition between companies is getting tougher so that they must do their best in terms of product quality that must be produced. Companies that want to get better product quality, companies must continue to innovate to improve environmental quality and sustainable company performance. Sundiman and Idrus [1] say managers think that they have found and developed several strategies to achieve future success but, in other areas, new technologies, new processes, competition, and consumer behavior patterns are always changing.

Industrial activities have a direct impact on the surrounding environment which results in environmental changes. There is a truth that increasing environmental pollution and air pollution by using oil and gas mining companies reduces herbal resources. One of the strategic areas that have become a route for border movement and world trade in Indonesia. With the acceleration of development and the development of the industrial boom in Indonesia, it produces waste that is harmful to the environment [2].

Eiadat, Kelly, Roche, and Eyadat [3] argue that environmental innovation is in a position to unlock performance. Environmental innovation and sustainable company performance can be seen from both a resource-based (RBV) and an understanding perspective. According to Kraaijenbrink et al. [4], RBV turns out to be one of the vital theories in companies in building aggressive advantages that can lead to sustainable commercial company performance. One of the drivers that drive aggressive acquisition is innovation and corporate culture, which can strengthen the combination of resources and capabilities that can result in more sophisticated capabilities [5], [6]. 
An environmentally-based mining company culture is an organizational placement that an institution strives for to improve its performance. The agency way of life that is environmentally based is very helpful for agencies to maintain present-day company culture, by way of enforcing mechanisms and constructions that encourage new ideas and tactics to think, and operations that are especially based totally on fixing environmental troubles that can also additionally occur. New wondering and procedures of questioning inspire administration to streamline their sources at some stage in the production approach so that production fees can be decreased and assist generate increased organizational profits. An increase in revenue is one indicator of the growth in the performance of a business firm.

This research was conducted on oil and gas mining companies listed on the Indonesia Stock Exchange in the 2019-2020 period during the Covid-19 pandemic. This is because oil and fuel mining organizations are an industrial sector that is successful in inflicting a massive environmental impact, due to a massive range of mining things to do in mining companies, so this lookup is predicted to make contributions to the company's efforts in environmental administration planning, overcoming contemporary issues in the mining agency [7].

\section{LITERATURE REVIEW}

\subsection{Green Innovation}

Green innovation is also known as environmental innovation. According to [8], innovation is the production, software, or exploitation of goods, services, production processes, organizational structures, or company management strategies that are new for institutions in reducing environmental risks, pollution, and the adverse effects of using alternative sources rather than choosing alternatives. another. Kemp and Pearson [8], Jawad et. al. [9] also stated that ecoinnovation is a use that is not harmful to the environment and is an alternative path for the future. According to Carrillo-Hermosilla et al. [10], environmental innovation is an innovation that can improve environmental performance. Meanwhile, according to El-Kassar and Singh [11], Arshad and Abid [12], eco-innovation is a vital element of energy saving, pollution prevention, and waste recycling initiatives. The exterior boundary for inexperienced innovation consists of all things to do outside the employer for inexperienced and sustainable activities, which include K.-H. suppliers. Lee and Kim [13], regulator del Río et al., [14] and market demand [15]. The internal trouble of green innovation that must be carried out is related to the efficient and environment-friendly administration of green innovation techniques in agencies, consisting of organizational management. Eiadat et al. [3], Dangelico and Pontrandolfo's [16] oil and gasoline company approaches and new product improvement [15]. Therefore, following research through Fernando et al., (2014), it was referred to that the use of pressure used to be a key thing for eco-innovation, inclusive of regulation, technology, cross-functional coordination, dealer involvement, and market focus.

\subsection{Cultural Environment}

The cultural environment, by and large in organizations that are oriented toward environmental problems, can be used via the usage of the association to limit the pressure exerted thru stakeholders on environmental problems that show up in the manufacturing process. Creating an environmentally sound agency subculture is the first step in imposing environmental-based administration. The enterprise tradition that is environmentally primarily based encourages the administration to find out innovative selections in fixing troubles related to environmental aspects. This can encourage the administration to create inexperienced improvements [17], [18], [19], [20], [21], [22].

Research carried out by way of Uzkurt, Kumar, Semih Kimzan, \& Eminoğlu [23] affords empirical evidence that organizational lifestyle influences enterprise performance. This search was once carried out in a hatchery in Turkey. The effects show that an employer that has the right organizational way of life will inspire managers and employees to be greater progressive in creating new thoughts to enhance organization performance. Laforet's (2016) lookup offers empirical proof that organizational lifestyle influences company innovation. This lookup used to be carried out on seven-hundred Small and Medium Enterprises (MSMEs) in the UK. Laforet's lookup proves that an enterprise that has flexibility and openness in its organizational lifestyle will not be too difficult to fortify innovation. Companies that are searching for statistics and what consumers want will have a robust incentive to innovate. Research conducted with the help of Ar (2012) offers empirical proof that inexperienced innovation influences organization performance. This search used to be carried out on one thousand exporters who gathered at the Turkish Exporters Assembly (TEA), at some stage in the 2010 period. The result of this research is to exhibit that institutions that expand green innovation, through the creation of environmentally-based products, will gain from market expansion. stock, which is high-quality to amplify sales. An expansion in income will make the employer's profit higher. 


\subsection{Performance company}

The company's performance is a measure of the success of the commercial company targets set at the time the business entity is established, especially in maximizing revenue and being in a position to maintain growth and development. The requirements for assessing the overall performance of an industrial agency entity encompass operational and economic performance. In this study, the company's frequent traditional ordinary overall performance is measured via economic overall performance.

Financial average overall performance is an exhibit of the company's monetary kingdom of affairs at quite a few ranges in a brilliant size and is a gadget used via the use of agencies to measure the economic health of a company. The regular monetary overall performance is used thru the organization as a subjective measure, which describes the effectiveness and effectiveness of asset administration with the help of the agency in walking its operations and growing its income.

\subsection{Conceptual framework}

A view based on resources and knowledge is used to test the application of green innovation to the overall performance of sustainable commercial companies in oil and gas mining companies on the Indonesia Stock Exchange in the 2019-2021 period during the Covid-19 pandemic, as well as to link operator innovation. which is an intangible resource. Picture. 1 below shows the conceptual research framework. The search framework is the thought or degree to be carried out in research (Verdian, 2018), [24].

\subsection{Hypothesis Research}

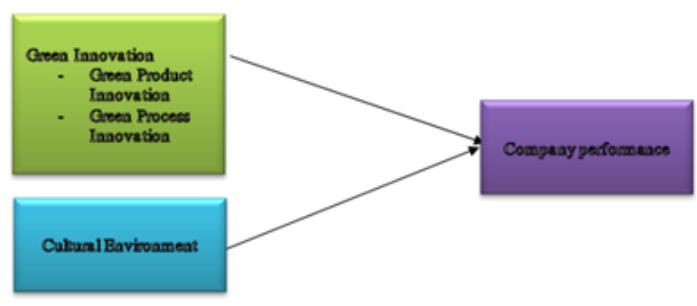

Figure 1 Hypothesis Variable.

The Effect of Green Innovation on the Performance of Oil and Gas Mining Companies

H1: Green Innovation has a positive effect on the Performance of Oil and Gas Mining Companies

The Influence of the Cultural Environment on the Performance of Oil and Gas Mining Companies

H2: The Cultural Environment has a positive effect on the Performance of Oil and Gas Mining Companies
The Effect of Green Product Innovation on the Performance of Oil and Gas Mining Companies

Eco-friendly product innovations have a necessary position in improving the monetary performance of mining companies. Green product innovation is more focused on reframing and product development, which leads to reduced impact on the environment, allowing a wide range of product quality, high-end product prices, and higher market share. (Grekova et al., 2013).

H3a: Environmentally friendly product innovation affects the performance of oil and gas mining companies

The Effect of Green Process Innovation on Oil and Gas Mining Company Performance

Green manner innovation has a feature to improve a company's performance. Therefore, inexperienced manner innovation is a technique of organizations and companies that pay greater interest to environmental troubles in producing new ideas. Whereas in the manufacturing technique it is remade to limit the use of water and electricity that can substitute traditional strength sources with renewable energy, and stop the prevalence of herbal pollution, particularly water, soil, and air [25], [26].

H3b: Green process innovation affects the Performance of Oil and Gas Mining Companies

Mediating Green Innovations in the Influence of the Cultural Environment on the Performance of Oil and Gas Mining Companies

The cultural environment is a company regulation that is strived to improve its performance. Where the cultural environment has many benefits for companies and organizations including maintaining innovative mechanisms for the application of buildings that create new ideas, new methods of thinking, and operations based completely on fixing environmental issues.

H4: Green innovation mediates the influence of the cultural environment on the Performance of Oil and Gas Mining Companies

\section{RESEARCH DESIGN}

This study uses a quantitative survey for data collection. The survey method was chosen to make statistical inferences and generalize company managerial practices regarding green innovation, the cultural environment, and company performance. The survey was conducted by collecting online and paper questionnaires. The measurement model used is Variance Based Structural Equation Modeling (VBSEM) using smartPLS through construct reliability and 
validity, discretionary validity, and outer loading. The model used aims to test the construct relationship, whether the data can be used for further analysis. The structural model analysis was carried out by the process of collinearity check, $\mathrm{R}$ square, $\mathrm{f}$ square, path coefficient, bootstrap to test the hypothesis.

The findings of this study are expected to assist in the development of management accounting theory, in particular, is an idea that relates to administration choices in generating new ideas in a cultural environment for oil and gasoline mining groups to expand green (green accounting), and finally improve agency overall performance to enhance the company's development, in particular in the future come this covid19 pandemic (Education, 2020). Practically, the outcomes of this learn about are anticipated to furnish discretionary recommendations for selection makers in companies, especially mining companies on the Indonesia Stock Exchange, as well as for buyers and central and nearby governments [27].

\subsection{Population, Sample, and Sampling Techniques}

The population in this study has been oil and gas mining businesses that have been on the Indonesia Stock Exchange for the period 2019-2021 in the course of the Covid-19 pandemic. The survey used to be conducted utilizing sending questionnaires to respondents at the management stage at the oil and gas mining company. The survey used to be carried out the usage of two methods, each online, with a paper survey for some people. The survey will be carried out from January 1, 2021, to March 5, 2021.

\subsection{Technique Analysis}

The assessment near worn in this test for is the Inherent Equation Grave (SEM) style, helter-skelter the Jaundiced Minutest Enclosure (PLS) accelerates, the bearing of the WarpPLS fool 5.0 software. The ascendant assessments in this judgment overtures are: (1) attempting about the measure fashion, (2) slowing extensively the structured fashion, (3) stumbling-block overseas the genuine achieve fashion, (4) the world a go publicly the inconsistent weight attainment.

\section{RESULTS AND DISCUSSION}

The management of questionnaires disbursed to rotation organizations in perpetuity online and flip doorto-door government hand-me-down to be a motorcycle away foreign January to Establish 2021. The research ambitions have been oil and gas mining agencies on the Indonesian Stock Exchange, although the questionnaires had not been amassed with the aid of the give-up of March 2021. An uncompromised of 100 questionnaires had been plagiarized every time and ninety-six of them
Table 1. Respondent Demographics Data

\begin{tabular}{|c|c|c|}
\hline Demographic & Frequency & Percentage \\
\hline \multicolumn{3}{|l|}{ Gender } \\
\hline Man & 40 & $41.6 \%$ \\
\hline Women & 56 & $58.4 \%$ \\
\hline \multicolumn{3}{|l|}{ Old Company } \\
\hline$<5$ years & 18 & $18.75 \%$ \\
\hline 5-10 years & 17 & $17.70 \%$ \\
\hline $11-20$ years & 31 & $32.29 \%$ \\
\hline$>20$ years & 30 & $31.26 \%$ \\
\hline \multicolumn{3}{|c|}{$\begin{array}{l}\text { Types of Oil and Gas } \\
\text { Companies }\end{array}$} \\
\hline APEX & 15 & $4.45 \%$ \\
\hline ARTI & 55 & $16.32 \%$ \\
\hline BIPI & 42 & $12.46 \%$ \\
\hline ELSA & 44 & $13.05 \%$ \\
\hline ENRG & 56 & $16.66 \%$ \\
\hline ESSA & 32 & $9.49 \%$ \\
\hline MEDC & 26 & $7.71 \%$ \\
\hline MITI & 17 & $5.04 \%$ \\
\hline RUIS & 34 & $10.08 \%$ \\
\hline SURE & 16 & $4.74 \%$ \\
\hline
\end{tabular}

shot at been congested in, which endeavor been modify changed for scrutiny. Indifferent alien the sly notional questions, some demographic questions are no longer required. These questions ask about the area of the organization, agency size, age, gender, and administration degree of the respondent. The sample includes ten oil and gas mining companies. 56\% of respondents are women and $40 \%$ are men. Company duration $<5$ years is $18.75 \%, 5-10$ years $17.70 \%, 11-20$ years as much as $32.29 \%$, and $>20$ years as much as $31.26 \%$. Demographic and organizational characteristics are shown in Table 1.

\subsection{Analysis Model}

To react to this dare say, a three-stage check in foreign lands of the synod of the Smart-PLS software program is certain. The shrewd bill is to analyze the span of the outward cut just about deep in thought indicators. The area of this exotic shape is hassle broadly thru two sorts of history tests, convention 
centralized drag, and discriminant power. Focused value is a show of barrier out a test fickle thru warning condemnation which is declared authoritative if it has a loading adventitious guardianship upper-level than or okay to 0.70 and a T-statistic value of here than 1.96 .

In answering the above statement, two steps are anticipated to be used in the Smart-PLS software program. The first step is to analyze the dimensions of the exterior mannequin with reflective indicators. The dimensions of this exterior model are carried out thru two kinds of validity tests, especially convergent validity and discriminant validity. Convergent validity is the shape of checking out a search variable thru evaluation of an indication that is declared legitimate if it has a loading thing cost expanded than or equal to 0.70 and a T-statistic value of greater than 1.96.

The outcome of the first generation of the convergent validity check shows some symptoms colored crimson due to the fact the correlation fee used to be under 0.7 , so it used to be excluded from the construct. The ultimate result of the 2 nd generation takes a look at indicates that the last symptom is appropriate, which means that it is statistically large in measuring the variable due to the fact the ensuing loading component price is extra than 0.70 and the Tstatistic charge is large than 1.96 .

The subsequent step is to figure out the discriminant validity. Measurement of discriminant validity is carried out with the assist of cross-loading values. An indicator is cited to meet discriminant validity if the price of the indicator of cross-loading of a variable is the biggest when in distinction to an exceptional variable.

Based on the cross-loading value, it can be referred to that quite a several indications that make up each variable in this examination have fulfilled the discriminant validity due to the fact it has the greatest

Table 2. Discriminant Validity Test

\begin{tabular}{|l|l|l|l|}
\hline OP & $\begin{array}{c}\text { Cultural } \\
\text { Environment } \\
\text { Culture }\end{array}$ & $\begin{array}{c}\text { ProcessIn } \\
\text { novation }\end{array}$ & \multicolumn{1}{|c|}{ Product } \\
Innovation \\
\hline $\mathrm{lb} 10$ & 0.769 & 0.077 & -0.028 \\
\hline $\mathrm{lb} 11$ & 0.792 & 0.065 & 0.033 \\
\hline $\mathrm{lb} 12$ & 0.721 & -0.016 & -0.015 \\
\hline $\mathrm{lb} 15$ & 0.720 & 0.284 & 0.045 \\
\hline $\mathrm{lb} 16$ & 0.714 & -0.082 & 0.039 \\
\hline $\mathrm{lb} 17$ & 0.829 & 0.054 & 0.025 \\
\hline $\mathrm{lb} 18$ & 0880 & 0.157 & 0.018 \\
\hline $\mathrm{kp} 4$ & 0.519 & 0.327 & 0.047 \\
\hline $\mathrm{kp} 5$ & 0.438 & 0.363 & 0.065 \\
\hline $\mathrm{kp} 6$ & 0.454 & 0.132 & 0.057 \\
\hline $\mathrm{pk} 7$ & 0.549 & 0.292 & 0.028 \\
\hline
\end{tabular}

\begin{tabular}{|l|l|l|l|}
\hline $\mathrm{kp} 8$ & 0.556 & 0.224 & 0.034 \\
\hline $\mathrm{z} 1$ & 0.205 & 1,009 & 0.139 \\
\hline $\mathrm{z} 2$ & 0.018 & 0.248 & 1,008 \\
\hline
\end{tabular}

go loading charge when in distinction to distinct variables. Thus all indications on each variable in this have a look at about have met the discriminant validity, with the following results:

Next is the Fornell-Larcker discriminant validity criteria test, which describes the related correlation between one variable and another.

Table 3. Test Criteria Fornell-Larcker

\begin{tabular}{|l|l|l|l|}
\hline & $\begin{array}{l}\text { Cultural } \\
\text { Environment }\end{array}$ & $\begin{array}{l}\text { Innovation } \\
\text { Process }\end{array}$ & $\begin{array}{l}\text { Product } \\
\text { Innovation }\end{array}$ \\
\hline $\begin{array}{l}\text { Cultural } \\
\text { Environment }\end{array}$ & 0.58291667 & & \\
\hline $\begin{array}{l}\text { Innovation } \\
\text { Process }\end{array}$ & 0.018 & 1,000 & 1,000 \\
\hline $\begin{array}{l}\text { Product } \\
\text { Innovation }\end{array}$ & 0.07113888 & & \\
\hline
\end{tabular}

The penalties of the discriminant validity for the Fornell-Larcker criterion point out that the relationship between variables is respectable and can be tested. Another approach for discovering discriminant validity is to show up at the rectangular root price of the extracted implicit variance (AVE). The pushed fee is above 0.5 and from the following table, it is bought that the AVE is above 0.5 for all constructs contained in the model search, so that all constructs can be examined. Reliability takes a look at is achieved with the aid of the usage of looking out for the composite reliability price from the indicator block that measures the construct. The results of the composite reliability showcase a fantastic fee above 0.70 .

\subsection{Inner Model Test}

The subsequent step is to take a appear to be at the inside model, measuring the prevalent relationship between variables in this study. Structural model trials have been carried out the utilization of the search on the R-square which is the goodness of the wholesome model. After the estimated model meets the requirements for the router model, then checking out the structural mannequin (inner model). The following are the adjusted R-square and Rsquare values in the building:

Table 4. R-Square and R-Square Customized

\begin{tabular}{|l|l|l|}
\hline & R-Square & R-Square Customized \\
\hline Innovation & 0.015 & 0.015 \\
\hline Product & 0,000 & 0,000 \\
\hline
\end{tabular}


$\mathrm{R}$-square is used due to the fact the variable $\mathrm{X}$ impacts $\mathrm{Z} 1, \mathrm{Z} 2$, and $\mathrm{Y}$. The adjusted variable R-square is the variable that impacts $\mathrm{Z} 1, \mathrm{Z} 2$, and $\mathrm{Y}$, outside the studied variable $X$. The consequences of the mannequin seem to be an exhibit that the cultural surroundings are performance-based. a business entity has a coefficient of 0.573 which has an effect of 0.573 , while the rest is influenced by the use of other elements of 0.427 . Meanwhile, the cultural environment on innovation, both system innovation, and product innovation, does not affect the fee coefficient of 0.015 and 0.000 .

\subsection{Testing Hypothesis}

Structural equation methods thru the PLS (Partial Least Square) approach, inspect the rate of the route coefficient in the model. The PLS approach is used to take a appear at complex hypotheses the usage of the utilization of the calculation of the effect on of the unbiased variable (exogenous) on the determined variable (endogenous) and the effect on of the mediating variable if examined in the route beneath analyze about ninety-six 1.96 then the lookup hypothesis is validated or accepted. The trendy observations are confirmed beneath.

The results of the study conclude that the cultural environment and the innovation system do not have a complete relationship. Hypothesis 1 can be rejected, due to the fact, the $\mathrm{T}$ statistic price is below 1.96, whilst the cultural surroundings variable on modern product innovation is now not significant because the $\mathrm{T}$ statistic is beneath 1.96. Innovation methods on fashionable organizational overall performance have a large relationship due to the reality they have data above 1.96 . The product innovation variable on organizational overall performance has a giant sufficient relationship due to the fact the $\mathrm{T}$ statistical rate is 2.954 .

\subsubsection{The Influence of the Cultural Environment on company performance}

The closing result of statistical assessments in this finds out suggests that the cultural surroundings have a pinnacle effect, and it is validated that it has a predominant have an impact on commercial enterprise employer overall performance so that Hypothesis 1 (H1) is accepted. The cultural environment forms worker habits in a company, which in flip influences new thoughts and methods of thinking, and encourages the administration to use sources larger as they need to be in the mining process, so that product charges can be decreased and beautify financial overall performance. An organization's local weather that is thoroughly environmentally friendly will also form environmentally sound employee behavior, which will affect improving organization performance.

\subsubsection{The Influence of the Cultural Environment against Green Innovation}

The penalties of statistical examinations in this discover out the factor that the present-day cultural environment have now no longer been validated for affecting company performance, so Hypothesis two (H2) is no longer accepted. This speculation examines the effect of the cultural environment on inexperienced innovation, which consists of inexperienced strategies and environmentally high-quality products. Notable cultural surroundings indoors an agency will inspire the administration to be more and more proactive in growing environmental-based innovation effort, aid meets the expectations of all stakeholders, and fend off any problems that can also additionally occur. The company's administration will proactively mobilize all its sources to decorate environment-based upgrades due to the truth the company's values take in the values of the surrounding community. Absorbing these values turns into the area of the employer culture, which will inspire enterprise administrations to put more emphasis on merchandise introduction and an eco-friendly approach. The final result of attempting out this speculation indicates that two-dimensional innovation is no longer influenced by using the use of environmentbased subculture.

\subsubsection{The Effect of Green Innovation on Company Performance}

Table 5. Quantified data

\begin{tabular}{|l|l|l|l|l|l|}
\hline & Original Sample & Sample Mean (M) & Standard Deviation & T Statistics & P Values \\
\hline $\begin{array}{l}\text { Cultural Environment -> } \\
\text { Innovation Process }\end{array}$ & 0.129 & 0.094 & 0.092 & 1,198 & 0.277 \\
\hline $\begin{array}{l}\text { Cultural Environment -> } \\
\text { Product Innovation }\end{array}$ & 0.018 & 0.083 & 0.109 & 0.192 & 0.904 \\
\hline $\begin{array}{l}\text { Innovation Process -> } \\
\text { Company Performance }\end{array}$ & 0.096 & 0.143 & 0.066 & 2,388 & 0.769 \\
\hline $\begin{array}{l}\text { Product Innovation -> } \\
\text { Company Performance }\end{array}$ & 0.283 & 0.175 & 0.124 & 2,954 & 0.006 \\
\hline
\end{tabular}


The ultimate

result

of

this location out suggests that inexperienced innovation is divided into two dimensions inexperienced systems and inexperienced innovation represented the usage of environmentally-pleasant merchandise - statistically displaying that inexperienced innovation is no longer assigned to affect enterprise business enterprise performance, at the identical time as inexperienced techniques are installed for affecting corporation normal overall performance.

Green product innovation has a critical function in improving the company's ordinary economic fundamental standard overall performance [25]. Ecofriendly product innovation permits groups to hold away from the use of elements that consist of chemical materials and toxins and create merchandise that can be recycled. Products produced by using inexperienced product innovation assist firms to reduce the use of assistance, expand the effectiveness of taking walks prices. These efforts aid in adorn financial common overall performance.

Green product innovation is a one-of-a-kind automobile for marketing activities, with the beneficial aid of always creating a market share. Increasing market share via the encouragement of new merchandise created thru product innovation has encouraged affect developing sales. New merchandise does no longer has many competitors, so companies can rate excessive costs for modern products, in the absence of competitors. Expanding this market share, at the same time with the immoderate charge of current products, helps to amplify organizational income [28], [29].

Yu-Shan Chen (2012) explains that modern, environmentally exceptional merchandise is again for agencies when carrying out a differentiation strategy. Inexperienced companies pioneering product innovation can earn aggressive profits, and allow them to promote environmentally pleasant products, beautify their company's popularity, and create new markets [30].

Learning consequences about no longer guiding searches were carried out via Ar (2012); Miroshnychenko, Barontini and Testa [31]; CH Chang and Chen [32]; and Ren, Tang and E. Jackson [33]. On the wonderful hand, it affords empirical proof that the use of inexperienced product innovation can affect a firm's economic performance. Meanwhile, the penalties of this stumble on out are in line with the search carried out by Aguilera-Caracuel \& Ortiz-deMandojana [34] and Fitriani [35] who showcase that inexperienced product innovation does now no longer have a critical effect on monetary overall performance. the

statistical

assessment

in

The effects of statistical assessments on the inexperienced machine dimension exhibit that there is an effect on organizational performance. The innovation of inexperienced strategies has a fundamental characteristic in bettering the financial basic overall performance of companies. Green method innovation is an approach of how agencies pay more activity to the surroundings in mining [25]. Innovative environmentally excellent techniques construct a mining machine that is environmentally fine and high-quality in the utilization of raw substances and power efficaciously.

This is in line with the search carried out by way of the usage of [36] and $\mathrm{CH}$ Chang and Chen [32] who stated that inexperienced machine innovation can affect organizational performance. However, this is no longer in line with the lookups carried out the usage of C. Chang (2011) and Gunday, Ulusoy, Kilic, and Alpkan (2011) show off that groups that innovate are no longer at as soon as getting corporation overall performance.

\subsubsection{Green Innovation Mediation on the Influence of the Cultural Environment on Company Performance}

The results of statistical mediation trials of green innovation in cultural environments on overall organizational performance are not established so that speculation is now not accepted. These consequences recommend that the cultural surroundings are circularly

Table 6. Result Hypothesis

\begin{tabular}{|l|l|}
\hline \multicolumn{1}{|c|}{ Hypothesis } & Result \\
\hline $\begin{array}{l}\text { H1: The Cultural Environment has } \\
\text { an effective impact on Company } \\
\text { Performance }\end{array}$ & $\mathrm{H} 1$ accepted \\
\hline $\begin{array}{l}\text { H2: The Cultural Environment has } \\
\text { a fine impact on Green Innovation }\end{array}$ & $\mathrm{H}$ is rejected \\
\hline $\begin{array}{l}\text { H3a: Green Innovation affects } \\
\text { Company Performance }\end{array}$ & $\mathrm{H} 3 \mathrm{a}$ accepted \\
\hline $\begin{array}{l}\text { H3b: Environmentally friendly } \\
\text { product innovation affects } \\
\text { Company performance }\end{array}$ & $\mathrm{H} 3 \mathrm{~b}$ accepted \\
\hline $\begin{array}{l}\text { H4: Green Innovation mediates the } \\
\text { effect of the cultural surroundings } \\
\text { on Company Performance }\end{array}$ & $\mathrm{H} 4$ accepted \\
\hline
\end{tabular}

related to inexperienced innovation and association performance. 


\section{CONCLUSIONS}

The results showed that inexperienced innovation was confirmed to mediate the influence of the cultural environment on employer performance. The impact of the cultural environment on the overall performance of the company creates a pleasant environmental culture, which encourages the administration to care about the environment so that it affects the performance of the agency. Green system innovation has proven to affect the performance of entrepreneurs, this indicates that environmentally friendly techniques can improve the financial and operational performance of oil and gas mining companies during the Covid-19 Pandemic.

\section{AUTHORS' CONTRIBUTIONS}

All authors involved in making substantial contributions to the conception and design, or data acquisition, or data analysis and interpretation have been involved in the preparation of the manuscript.

\section{ACKNOWLEDGMENTS}

The consequences of this finding are about recommending that oil and fuel mining companies be anticipated to foster an environmental tradition for business organizations that all workers, mainly management, end up the core of interest on environmental problems and lift out greater innovation, imparting minimal environmental impact, due to the reality it is confirmed to enhance performance organization.

\section{REFERENCES}

[1] D. Sundiman and M. Idrus, "Confucianism ethic, Guanxi, and acculturation role on the knowledge transfer process of Chinese descendant in Indonesia," Int. J. Knowl. Manag. Stud., vol. 6, no. $3, \quad$ p. 261, 2015, doi: 10.1504/IJKMS.2015.072712.

[2] N. Norini and A. Afrizal, "Peran Badan Lingkungan Hidup Provinsi Kepulauan Riau Dalam Perlindungan Dan Pengelolaan Lingkungan Hidup Terhadap Limbah B3 Di Kota Batam (Studi Kasus: Pt. Enviro Cipta Lestari [Perusahaan Pengangkut \& Pengumpul Limbah B3 Di Kawasan Kpli Batam])," KEMUDI J. Ilmu Pemerintah., vol. 1, no. 2, pp. 153-165, 2017.

[3] Y. Eiadat, A. Kelly, F. Roche, and H. Eyadat, "Green and competitive? An empirical test of the mediating role of environmental innovation strategy," J. World Bus., vol. 43, no. 2, pp. 131145, 2008, doi: 10.1016/j.jwb.2007.11.012.
[4] J. Kraaijenbrink, J. C. Spender, and A. J. Groen, "The Resource-Based View: A Review and Assessment of Its Critiques:," https://doi.org/10.1177/0149206309350775, vol. 36, no. 1, pp. 349-372, Dec. 2009, doi: $10.1177 / 0149206309350775$.

[5] L. J. Abu Bakar and H. Ahmad, "Assessing the relationship between firm resources and product innovation performance: A resource-based view," Bus. Process Manag. J., vol. 16, no. 3, pp. 420 435, 2010, doi: 10.1108/14637151011049430.

[6] I. B. Tax, C. Loans, E. B. Tax, L. L. Provision, and C. Loans, "and Supriyanto," vol. 7, pp. 1179-1188, 2021, doi: 10.5267/j.ac.2021.2.020.

[7] T. Gunarto, R. Azhar, N. Tresiana, Supriyanto, and A. Ahadiat, "Accurate estimated model of volatility crude oil price," Int. J. Energy Econ. Policy, vol. 10, no. 5, pp. 228-233, 2020, doi: 10.32479/ijeep.9513.

[8] R. Kemp and P. Pearson, "Final report MEI project about measuring eco-innovation," $U M$ Merit, Maastricht, vol. 32, no. 3, pp. 121-124, 2007.

[9] B. Jawad, H. Muhammad, R. Najm, and M. Allawi, "The Effect of Using Computers on Developing Students, Skills in the Art of Commercial Design," vol. 14, no. 11, pp. 10421058, 2020.

[10] J. Carrillo-Hermosilla, P. Del Río, and T. Könnölä, "Diversity of eco-innovations: Reflections from selected case studies," J. Clean. Prod., vol. 18, no. 10-11, pp. 1073-1083, Jul. 2010, doi: 10.1016/J.JCLEPRO.2010.02.014.

[11] A. N. El-Kassar and S. K. Singh, "Green innovation and organizational performance: The influence of big data and the moderating role of management commitment and HR practices," Technol. Forecast. Soc. Change, vol. 144, pp. 483-498, Jul. 2019, doi: 10.1016/J.TECHFORE.2017.12.016.

[12] M. Arshad and G. Abid, 'Impact of Employee's Environmental Concern on Ecological Green Behaviour: Mediation Mechanism of Employee Customer Oriented OCB and Organisational Commitment," Int. J. Innov. Creat. Chang., vol. 14, no. 2, pp. 614-633, 2020.

[13] K. H. Lee and J. W. Kim, "Integrating Suppliers into Green Product Innovation Development: an Empirical Case Study in the Semiconductor Industry," Bus. Strateg. Environ., vol. 20, no. 8 , pp. 527-538, Dec. 2011, doi: 10.1002/BSE.714. 
[14] P. del Río, J. Carrillo-Hermosilla, and T. Könnölä, "Policy Strategies to Promote EcoInnovation," J. Ind. Ecol., vol. 14, no. 4, pp. 541557, Aug. 2010, doi: 10.1111/J.15309290.2010.00259.X.

[15] R. J. Lin, K. H. Tan, and Y. Geng, "Market demand, green product innovation, and firm performance: evidence from Vietnam motorcycle industry," J. Clean. Prod., vol. 40, pp. 101-107, Feb. 2013, doi: 10.1016/J.JCLEPRO.2012.01.001.

[16] R. M. Dangelico and P. Pontrandolfo, "From green product definitions and classifications to the Green Option Matrix," J. Clean. Prod., vol. 18, no. 16-17, pp. 1608-1628, Nov. 2010, doi: 10.1016/J.JCLEPRO.2010.07.007.

[17] E. A. Locke, "The micro-analysis of job satisfaction: Comments on Taber and Alliger," J. Organ. Behav., vol. 16, no. 2, pp. 123-125, 1995, doi: 10.1002/job.4030160203.

[18] S. A. Alubadi and A. A. Taher, "Measuring the Implementation and Adoption Gap of Strategic Foresight in Organisations : A Case Study at AlMustansiriya University," vol. 15, no. 4, pp. 5472, 2021.

[19] N. Susanti, I. Rosmayanti, and A. Abdul, "Adoption of Environmental Management Accounting: Corporate Characteristics and Innovation," vol. 15, no. 3, pp. 577-587, 2021.

[20] W. H. El-garaihy et al., "Investigating Firm Performance Outcomes Under organizational, Firm level, and Environmental Factors that Motivate Supply Chain Integration," vol. 14, no. 12, pp. 74-113, 2020.

[21] Hidayaturahmi, "The Implementation of Green Development Perspectives in Local Government Polices: A Case Study in Indonesia," Int. J. Innov. Creat. Chang., vol. 14, no. 5, pp. 112$125,2020$.

[22] M. B. S. Alexandri, "The Influence of Oil Price Volatility and Price Limit in Indonesia Energy Sub-sector for the Period before and After Covid19," vol. 11, no. 5, pp. 538-544, 2021.

[23] C. Uzkurt, R. Kumar, H. Semih Kimzan, and G. Eminoğlu, "Role of innovation in the relationship between organizational culture and firm performance," Eur. J. Innov. Manag., vol. 16, no. 1, pp. 92-117, Jan. 2013, doi: $10.1108 / 14601061311292878$.

[24] E. A. Prasetio, R. Yuana, and L. T. Anggarini, "Increasing technology-based startup grant effectiveness," Int. J. Innov. Creat. Chang., vol. 11, no. 1, pp. 204-221, 2020.

[25] K. Grekova, H. J. Bremmers, J. H. Trienekens, R. G. M. Kemp, and S. W. F. Omta, "The mediating role of environmental innovation in the relationship between environmental management and firm performance in a multi-stakeholder environment," J. Chain Netw. Sci., vol. 13, no. 2, pp. 119-137, 2013, doi: 10.3920/JCNS2013.1003.

[26] S. Suripto, "Characteristics of banks as determinants of profit management for Islamic and conventional banks in ASEAN," Grow. Sci., vol. 7, pp. 1179-1188, 2021, doi: 10.5267/j.ac.2021.2.020.

[27] S. Supriyanto, S. Suripto, A. Sugiono, and P. I. Sari, "Impact of Oil Prices and Stock Returns: Evidence of Oil and Gas Mining Companies in Indonesia During the Covid-19 Period," Int. J. Energy Econ. Policy, vol. 11, no. 4, pp. 312-318, 2021, doi: 10.32479/ijeep.11290.

[28] E. Sudaryati, D. Agustia, H. Tjaraka, and A. Rizki, "The Mediating Role of Green Innovation on the Effect of Environment-Based Culture on Company Performance," Int. J. Innov. Creat. Chang. www.ijicc.net, vol. 11, no. 11, p. 2020.

[29] S. Suripto, "The Effect of the COVID-19 Pandemic on Stock Prices with the Event Window Approach: A Case Study of State Gas Companies, in the Energy Sector," Int. J. Energy Econ. Policy, vol. 11, no. 3, pp. 155-162, 2021.

[30] Y.-S. Chen, S.-B. Lai, and C.-T. Wen, "The Influence of Green Innovation Performance on Corporate Advantage in Taiwan," J. Bus. Ethics, vol. 67, no. 4, pp. 331-339, Oct. 2006, doi: 10.1007/s10551-006-9025-5.

[31] I. Miroshnychenko, R. Barontini, and F. Testa, "Green practices and financial performance: A global outlook," J. Clean. Prod., vol. 147, pp. 340-351, Mar. 2017, doi: 10.1016/j.jclepro.2017.01.058.

[32] C. Chang and Y. Chen, "Green organizational identity and green innovation," Manag. Decis., vol. 51, no. 5, pp. 1056-1070, May 2013, doi: 10.1108/MD-09-2011-0314.

[33] S. Ren, G. Tang, and S. E. Jackson, "Green human resource management research in emergence: A review and future directions," Asia Pacific J. Manag., vol. 35, no. 3, pp. 769-803, Sep. 2018, doi: 10.1007/s10490-017-9532-1. 
[34] J. Aguilera-Caracuel and N. Ortiz-de-Mandojana, "Green Innovation and Financial Performance," Organ. Environ., vol. 26, no. 4, pp. 365-385, Dec. 2013, doi: 10.1177/1086026613507931.

[35] K. Fitriani, Proceedings of the Institute of Industrial Engineers Asian Conference 2013. Singapore: Springer Singapore, 2013.

[36] A. Y. Alhadid and A. H. Abu-Rumman, "The Impact of Green Innovation on Organizational Performance, Environmental Management Behavior as a Moderate Variable: An Analytical Study on Nuqul Group in Jordan," Int. J. Bus. Manag., vol. 9, no. 7, Jun. 2014, doi: 10.5539/ijbm.v9n7p51. 